\title{
Physiotherapists' knowledge on the provision of physiotherapy to people with mental illness. A study from Paraguay
}

\author{
Conocimiento de los fisioterapeutas sobre la provisión de fisioterapia a \\ personas con enfermedad mental. Un estudio de Paraguay
}

\author{
Marcos Almirón $\mathbb{B}^{1}$, Iván Barrios $\mathbb{B}^{1,2}$, Marcelo O'Higgins $\mathbb{B}^{2}$; Israel González $\mathbb{B}^{2}$, \\ João Mauricio Castaldelli-Maia $\mathbb{B}^{3,4}$, Antonio Ventriglio $\mathbb{B}^{5}$, Julio Torales $\left(\mathbb{C}^{1,2}\right.$
}

\begin{abstract}
${ }^{1}$ Universidad Nacional de Asunción, Facultad de Ciencias Médicas, Departamento de Metodología de la Investigación, San Lorenzo, Paraguay. 2 Universidad Nacional de Asunción, Facultad de Ciencias Médicas, Departamento de Psiquiatría, San Lorenzo, Paraguay.

${ }^{3}$ Fundação do ABC, Department of Neuroscience, Santo André, SP, Brazil.

${ }^{4}$ University of São Paulo, Department of Psychiatry, São Paulo, SP, Brazil.

${ }^{5}$ University of Foggia, Department of Clinical and Experimental Medicine, Foggia, Italy.
\end{abstract}

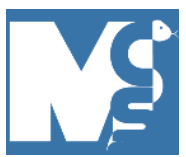

Received: $23 / 06 / 2020$

Revised: $19 / 08 / 2020$

Accepted: 21/09/2020

Corresponding author

Julio Torales

National University of Asunción

San Lorenzo - Paraguay

jtorales@med.una.py

\section{Conflicts of interests}

The authors declare that there is no conflict of interest.

\section{Funding}

The authors received no financial support for the research, authorship, and/or publication of this article.

This article is published under Creative Commons Attribution 4.0 International License.

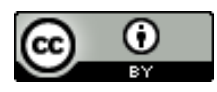

\section{ABSTRACT}

Introduction: Physiotherapy improves the quality of life in people with mental disorders through the optimization of their physical and mental health. This study aimed to determine the knowledge of physiotherapists about the provision of Physiotherapy services to people with mental disorders, about the role of Physiotherapy in the treatment of physical illnesses of mentally ill persons and in the treatment of the mental disorder itself. Methodology: A descriptive, observational, cross-sectional, and prospective study was conducted. 187 physiotherapists practicing in Paraguay, of both sexes, were surveyed. The data collection instrument was a Spanish version of the survey used by Andrew et al., which was adapted. Results: $46.52 \%$ of physiotherapists stated that Physiotherapy is useful to manage the physical symptoms of people with mental disorders. 55.61\% reported that they needed more information and/or training on managing physical conditions affecting these people. $75.94 \%$ declared that they were aware that Physiotherapy can be used as treatment for some mental disorders, mainly as an adjuvant treatment to both pharmacotherapy and psychotherapy (54.55\%). Participants scored anxiety disorders (23.88\%), major depression disorder (21.99\%) and Alzheimer's disease $(21.48 \%)$ as those conditions that could most benefit from a physiotherapeutic intervention. Also, $21.93 \%$ of the respondents reported the need of more information on how to interact and communicate with people with mental disorders. Conclusion: There are gaps in the knowledge of physiotherapists in Paraguay about the provision of Physiotherapy to people with mental disorders.

Keywords: Physiotherapy; mental health; mental disorders.

\section{RESUMEN}

Introducción: la fisioterapia mejora la calidad de vida de las personas con trastornos mentales mediante la optimización de su salud física y mental. Este estudio tuvo como objetivo determinar el conocimiento de los fisioterapeutas sobre la prestación de servicios de Fisioterapia a personas con trastornos mentales, sobre el papel de la Fisioterapia en el tratamiento de las enfermedades físicas de los enfermos mentales y en el tratamiento del propio trastorno mental. Metodología: se realizó un estudio descriptivo, observacional, transversal y prospectivo. Se encuestó a 187 fisioterapeutas que ejercen en Paraguay, de ambos sexos. EI instrumento de recolección de datos fue una versión en español de la encuesta utilizada por Andrew y colaboradores, La cual fue adaptada. Resultados: el 46,52\% de los fisioterapeutas afirmó que la fisioterapia es útil para controlar los síntomas físicos de las personas con trastornos mentales. El 55,61\% informó que necesitaba más información y/o capacitación sobre el manejo de las condiciones físicas que afectan a estas personas. El 75,94\% declaró conocer que la fisioterapia puede utilizarse como tratamiento para algunos trastornos mentales, principalmente como tratamiento adyuvante, tanto de la farmacoterapia como de la psicoterapia $(54,55 \%)$. Los participantes calificaron a los trastornos de ansiedad $(23,88 \%)$, al trastorno de depresión mayor $(21,99 \%)$ y a la enfermedad de Alzheimer $(21,48 \%)$ como las afecciones que más podrían beneficiarse de una intervención fisioterapéutica. Además, el 21,93\% de los encuestados reportó la necesidad de mayor información sobre cómo interactuar y comunicarse con personas con trastornos mentales. Conclusión: existen lagunas en el conocimiento de los fisioterapeutas en Paraguay sobre la provisión de fisioterapia a personas con trastornos mentales.

Palabras clave: trabajadores de la salud; salud mental; COVID-19; ansiedad; depresión; estrés postraumático 


\section{INTRODUCTION}

Mental, neurological and substance use disorders contribute to a significant proportion of disease burden worldwide. These disorders are considered the third leading cause of disability-adjusted life years (DALYs) after cardiovascular and circulatory diseases as well as diarrhea, lower respiratory infections, meningitis, and other common infectious diseases (1). For example, depression is a leading contributor to the global burden of disease and is nowadays a common chronic disease affecting the personal functioning and quality of life (2). Even if most patients may benefit from pharmacological and/or psychotherapeutic treatment, many other patients may need adjuvant approaches, such as physiotherapy (3).

People with severe and persistent mental disorders (e.g. schizophrenia, bipolar disorder and major depression disorder) (4-7) report poor physical health and high rates of comorbid medical illnesses (respiratory and cardiovascular diseases, diabetes mellitus and obesity, among others) (8). For example, people with mental disorders are 2-3 times more likely to develop cardiovascular disease, they have an increased prevalence of metabolic syndrome, and their life expectancy is 15 to 25 years lower than in the general population $(9,10)$. These poor physical health conditions may be due to the mental disorder itself and the adverse effects of psychotropic drugs (e.g. antipsychotics), which are associated with metabolic and endocrine changes (11). In addition, these patients are more likely to be involved in negative habits such as smoking, substance abuse, lack of physical activity, and the practice of unhealthy lifestyles (12).

Physiotherapy can improve the quality of life of people with mental disorders $(13,14)$. This may be achieved through the optimization of their physical health as well as the relief of their psychosocial disability (15), and through its role as an adjuvant treatment of the mental disorder itself $(16,17)$. There is evidence that improvements in muscle balance and flexibility are associated with a feeling of increased safety and increased self-esteem. In addition, an improved posture can benefit the body self-image and improve the mood, as well as decrease bodily pain. There is also strong evidence that an adequate regimen of physical exercise improves the well-being of people with mental disorders, such as depression and anxiety $(17,18)$.

Despite these benefits, researchers (19) have stated that people with mental disorders do not regularly access Physiotherapy services for the management of their physical health problems and that there is still a lack of awareness on the role of Physiotherapy in mental health (20).

A recent study surveyed 88 physiotherapists (4) confirming that they do report the need of training opportunities in mental health, education in this area during the graduate school and professional development opportunities in Physiotherapy in mental health.

Some studies have focused on the barriers for people with mental disorders in accessing Physiotherapy services from the point of view of Mental Health professionals (20), in determining the factors that influence the provision of Physiotherapy in the physical health management of people with mental disorders from the point of view of physiotherapists (4), or in recognizing the positive impact of Physiotherapy in the management of the physical health of people with mental disorders (21-24). Poor evidence is available on the knowledge about the role of Physiotherapy as an adjuvant treatment of mental disorders, not only for physical diseases affecting mentally ill persons.

This study aimed to determine the knowledge of physiotherapists about the provision of Physiotherapy services to people with mental disorders, about the role of Physiotherapy in the treatment of physical illnesses of mentally ill persons and in the treatment of the mental disorder itself.

\section{METHODOLOGY}

This was a pilot, descriptive, cross-sectional, and prospective observational study. A non-probabilistic sampling of consecutive cases was used. During the months of November 2019 to March 2020, a survey was carried out that included 187 physiotherapists in Paraguay, of both sexes, who agreed to participate in the research.

\section{Instrument}

The data collection instrument was a Spanish version of the survey used by Andrew et al. (4) in Australia, which was adapted. The translation and adaptation of the instrument was carried out with the authorization of the original authors. The survey has been spread through Google Forms and distributed to mailing lists of physiotherapists practicing in Paraguay, inviting them to participate in the research. The survey contained closed (single-choice or multiple-choice) and open-ended questions, designed to collect information on participants' knowledge about the physiotherapy treatment of people with mental disorders (frequency of care for people with mental disorders; attitudes and knowledge about people with mental disorders, among others) and on the contribution of Physiotherapy in the treatment of mental disorders (its perceived role and 
the need for professional development in the area of Mental Health, among others). In addition, the survey contained a section to collect sociodemographic and professional information (age, sex, years of experience as a physical therapist, primary area of professional practice, area of work, main place of employment, location of employment and previous experience working in an environment of Mental Health services).

The data were processed using Microsoft Excel. Descriptive statistics were performed for all variables with central trend and dispersion measurements.

\section{Ethical issues}

This study is part of the research line "Physiotherapy in Mental Health", approved by Resolution No. 1163-00-
2019 of the Dean of the School of Medicine of the National University of Asuncion, Paraguay. Data were treated with confidentiality, equality, and justice, respecting the Helsinki principles.

\section{RESULTS}

187 physiotherapists completed the survey. $75.94 \%$ were women (142 participants). The mean age was 32.84 years, with a standard deviation of 7.95 years. The average number of years of experience as physical therapist was $8.47 \pm 7.30$ years. $49.2 \%$ graduated from a private University or Higher Institute, $34.22 \%$ worked in Trauma Physiotherapy and $87.7 \%$ worked with outpatients. The rest of the sociodemographic and professional data are shown in Table 1.

TABLE 1. SOCIODEMOGRAPHIC AND PROFESSIONAL CHARACTERISTICS OF THE PARTICIPANTS ( $n=187)$.

\begin{tabular}{|c|c|c|}
\hline \multirow{2}{*}{ Characteristics } & \multicolumn{2}{|c|}{ Frequency } \\
\hline & $\mathrm{n}$ & $\%$ \\
\hline \multicolumn{3}{|l|}{ University of origin } \\
\hline Private universities and institutes & 85 & 45.45 \\
\hline National University of Asunción & 83 & 44.39 \\
\hline Foreign universities & 19 & 10.16 \\
\hline \multicolumn{3}{|l|}{ Main professional practice area } \\
\hline Trauma physiotherapy & 64 & 34.22 \\
\hline Neurological physiotherapy & 31 & 16.58 \\
\hline Pediatric physiotherapy & 19 & 10.16 \\
\hline Sports physiotherapy & 17 & 9.09 \\
\hline Geriatric physiotherapy & 16 & 8.56 \\
\hline Cardiorespiratory physiotherapy & 16 & 8.56 \\
\hline Physiotherapy in ICU & 7 & 3.74 \\
\hline Physiotherapy in palliative care & 3 & 1.60 \\
\hline Dermato-functional physiotherapy & 3 & 1.60 \\
\hline Aesthetic physiotherapy & 2 & 1.07 \\
\hline Other & 9 & 4.81 \\
\hline \multicolumn{3}{|l|}{ Type of patients } \\
\hline Outpatient & 164 & 87.70 \\
\hline Inpatient & 23 & 12.30 \\
\hline \multicolumn{3}{|l|}{ Main scope of work } \\
\hline Hospital/Private Center & 145 & 77.54 \\
\hline Hospital/Public Center & 42 & 22.46 \\
\hline \multicolumn{3}{|l|}{ Location of the workplace } \\
\hline Rural & 5 & 24.06 \\
\hline Urban & 182 & 75.94 \\
\hline
\end{tabular}

Knowledge on the physiotherapeutic treatment of physical illnesses affecting people with mental disorders

$82.89 \%$ reported no previous experience in a Mental Health service and $61.50 \%$ reported a lack of information about the management of physical conditions affecting people with mental disorders.
46.52\% stated that Physiotherapy is useful to manage physical symptoms in these patients and $35.83 \%$ reported that physiotherapy should be largely provided to mentally ill subjects. $55.61 \%$ asked for more information and/or training on the management of physical conditions affecting people with mental disorders. Table 2 shows these results in more detail. 
TABLE 2. KNOWLEDGE OF THE PHYSIOTHERAPEUTIC TREATMENT OF PHYSICAL DISEASES AFFECTING PEOPLE WITH MENTAL DISORDERS. PART 1 ( $n=187)$.

\begin{tabular}{lll}
\hline \multirow{2}{*}{ Questions } & \multicolumn{2}{l}{ Participants } \\
& $\mathrm{n}$ & $\%$ \\
\hline Work-experience in a Mental Health Service & 32 & 17.11 \\
Yes & 155 & 82.89 \\
No & & \\
& & \\
Do you agree that Physiotherapy plays a significant & & \\
role in managing the physical conditions of people & & \\
with mental disorders? & & \\
Agree. & 87 & 46.52 \\
Strongly agree. & 74 & 39.57 \\
Neutral & 25 & 13.37 \\
Disagree & 1 & 0.53 \\
& & \\
Would you like to care for more people with mental & & \\
disorders in your professional practice? & & \\
Maybe & 67 & 35.3 \\
Neutral & 67 & 35.83 \\
Definitely yes & 22 & 11.76 \\
Maybe not & 19 & 10.16 \\
Definitely not & 12 & 6.42 \\
& & \\
Do you need more information and/or training on the & & \\
management of physical conditions affecting people & & \\
with mental disorders? & 104 & 55.61 \\
Definitely yes & 60 & 32.09 \\
Maybe & 12 & 6.42 \\
Neutral & 7 & 3.74 \\
Maybe not & 4 & 2.14 \\
Definitely not & & \\
\hline & & \\
\hline
\end{tabular}

41.18\% reported that less than a quarter of their patients are people with mental disorders. $23.53 \%$ reported that this proportion may be due to an inadequate knowledge about the physiotherapeutic treatment of mentally ill people. More information can be found in Table 3.

$35.83 \%$ of participants reported feeling somewhat confident to interact and communicate with people with mental disorders. $14.97 \%$ felt that their workplace was somewhat prepared to treat the physical illnesses affecting people with mental disorders and $32.62 \%$ reported that they felt somewhat prepared to manage these physical conditions (cardiovascular diseases, respiratory diseases, metabolic syndrome and diabetes, among others). Figure 1 summarizes these findings.

TABLE 3. KNOWLEDGE OF THE PHYSIOTHERAPEUTIC TREATMENT OF PHYSICAL DISEASES AFFECTING PEOPLE WITH MENTAL DISORDERS. PART 2 ( $n=187)$.

\begin{tabular}{lll}
\multicolumn{1}{c}{ Questions } & Participants \\
& $\mathrm{n}$ & \multicolumn{1}{c}{$\%$} \\
\hline $\begin{array}{ll}\text { What is the proportion of patients with mental } \\
\text { disorders of the total cases you treat? }\end{array}$ & & \\
About half & 28 & 14.97 \\
Most of them & 8 & 4.28 \\
Less than a quarter & 77 & 41.18 \\
None & 74 & 39.57 \\
& & \\
What is the reason for this proportion? & & \\
Lack of professional referrals & 26 & 13.90 \\
Inadequate knowledge on physiotherapeutic treatment & 44 & 23.53 \\
of people with mental disorders & & \\
Subject not discussed with the patient & 17 & 9.09 \\
Preference to care for people without mental disorders & 22 & 11.76 \\
Other & 78 & 41.71 \\
\hline
\end{tabular}




\begin{tabular}{lll} 
What is the most common physical condition you & & \\
manage in people with mental disorders? & & \\
Musculoskeletal diseases & 17 & 9.09 \\
Poor cardiovascular condition & 3 & 1.60 \\
Neurological & 1 & 0.53 \\
Obesity & 1 & 0.53 \\
Other / Did not respond & 165 & 88.24 \\
& & \\
The people who attended the consultation were & & \\
lsolated cases & 75 & 40.11 \\
Never attended & 35 & 18.72 \\
Cases derived by a general practitioner & 25 & 13.37 \\
Cases reported by a traumatologist & 14 & 7.49 \\
Cases derived by a psychologist & 11 & 5.88 \\
Cases derived by a psychiatrist & 10 & 5.35 \\
Case derived by a neurologist & 1 & 0.53 \\
Other & 16 & 8.56 \\
\hline
\end{tabular}

FIGURE 1. CONFIDENCE IN THE MANAGEMENT OF PEOPLE WITH MENTAL DISORDERS ( $n=187)$.

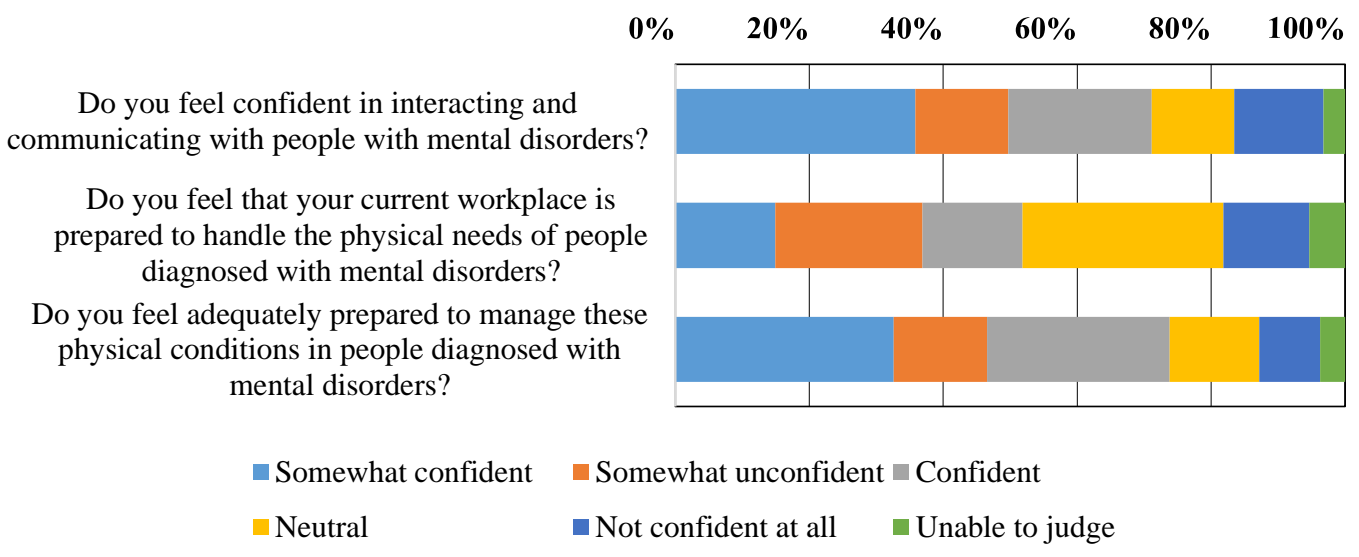

The need of more information for the management of the physical difficulties of people with mental disorders included: a. How physiotherapists can manage physical conditions that afflict people with mental disorders (39.04\%); b. How to interact and communicate with people with mental disorders, their relatives and / or caregivers $(21.93 \%)$; c. How to assess the behavioral risk of people with mental disorders, for example: risk of aggressiveness towards health personnel (16.04\%); d. Physical conditions commonly associated with mental disorders (11.23\%); e. Information on mental disorders in general, for example: symptoms, clinical presentation, available treatments (8.02\%); and, f. All of the above (3.74\%).

Knowledge of Physiotherapy as a treatment for mental disorders

$75.94 \%$ of the participants stated that they were aware that Physiotherapy can be used as treatment for some mental disorders, mainly as an adjunct to both pharmacotherapy and psychotherapy (54.55\%).

Jacobson's progressive muscle relaxation and aerobic exercise were considered to be effective in the treatment of some mental disorders $(22.32 \%$ and $21.47 \%$, respectively).

Participants mentioned that anxiety disorders (23.88\%), major depression and related disorders (21.99\%), and Alzheimer's disease and other dementias (21.48\%) could mostly benefit from physiotherapy treatment. Table 4 presents these results in detail.

$20.3 \%$ of sample reported to be aware on the existence of services providing Physiotherapy in the treatment of mental disorders in Paraguay. The "Hospital de Clínicas" of the School of Medicine, at National University of Asunción, was one of the most recognized health services (50\%). 
TABLE 4. KNOWLEDGE OF PHYSIOTHERAPY IN THE MANAGEMENT OF MENTAL DISORDERS (N=187).

\begin{tabular}{lll}
\multicolumn{1}{c}{ Questions } & \multicolumn{2}{c}{ Participants } \\
& \multicolumn{1}{c}{$\mathrm{n}$} & $\%$ \\
\hline Physiotherapy can be used as a treatment for some mental disorders & & \\
Yes & 142 & $75.94 \%$ \\
No & 45 & $24.06 \%$
\end{tabular}

$\begin{array}{lll}\text { What do you think is the role of Physiotherapy in the treatment of mental } & & \\ \text { disorders? } & 1 & 0.53 \\ \text { Can be used as a monotherapy } & 11 & 5.88 \\ \text { Can be used as an adjuvant of pharmacotherapy } & 31 & 16.58 \\ \text { Can be used as an adjuvant of psychotherapy } & 102 & 54.55 \\ \text { It can be used as an adjuvant of pharmacotherapy and psychotherapy } & 9 & 4.81 \\ \text { None of the above } & 33 & 17.65 \\ \text { All of the above } & \end{array}$

Have you prescribed any physiotherapeutic treatment for the treatment of any mental disorder?

Yes

No

From the following list, what do you think is a physiotherapy intervention with positive evidence for the treatment of some mental disorders? (you can select more than one intervention)

Basic body-awareness therapy

Muscle strengthening

Aerobic exercise

Yoga

Progressive muscle relaxation

Manual therapy

Other

$\begin{array}{ll}74 & 15.58 \\ 43 & 9.05 \\ 102 & 21.47 \\ 62 & 13.05 \\ 106 & 22.32 \\ 75 & 15.79 \\ 13 & 2.74\end{array}$

From the following list, what do you think is a mental disorder that can benefit from physiotherapy? (you can select more than one disorder) Anxiety disorders

Major depression and related disorders

Alzheimer's disease and other dementias

Eating disorders

528.93

Bipolar disorder and related disorders

Schizophrenia and other psychotic disorders

Do not know

$34 \quad 5.84$

$7 \quad 1.20$

\section{DISCUSSION}

To the best of our knowledge, this is the first research carried out in a Spanish-speaking country in order to determine the knowledge that physiotherapists have about the provision of Physiotherapy to people with mental disorders and about the role of Physiotherapy in the treatment of the physical illnesses of people with mental conditions, as well as those related to the use of Physiotherapy in the treatment of mental disorders. Although there is a similar work done in Australia (4), it focused on studying physiotherapists' perceptions of their role in the management of people with mental disorders, as well as the barriers they identified in the provision of Physiotherapy services for this population, but did not measure knowledge regarding the use of Physiotherapy as a treatment for mental disorders.
In this study, more than $80 \%$ of surveyed Physiotherapists recognized that Physiotherapy plays a significant role in the management of physical conditions affecting people with mental disorders, and almost $50 \%$ of the participants would like to treat more people with these comorbidities. This is in line with what was reported by Andrew et al. (4), who in their study found that the majority considered that the treatment of people with mental disorders was part of their work and that Physiotherapy had an important role in the management of physical diseases that affect this population.

Likewise, our results may support the evidence of a positive attitude of physical therapists in managing physical illnesses of people with mental disorders (2124). However, this research also showed the existence of some barriers to this. Although $35.83 \%$ of 
participants reported feeling somewhat confident and/or capable of interacting and communicating with people with mental disorders, and $32.62 \%$ stated they felt somewhat able of managing physical frequent comorbidities (cardiovascular diseases, respiratory diseases, metabolic syndrome and diabetes), more than $60 \%$ reported that they could not access information about the management of these physical conditions. Furthermore, more than half of surveyed physiotherapists reported the need of more information and/or training regarding the management of physical conditions affecting people with mental disorders. This is a clear sign of the lack of an adequate training at undergraduate and graduate levels, as confirmed by previous findings (25).

Connaughton and Gibson (25) identified gaps in knowledge about mental illness among Physiotherapy students (due to insufficient content in the undergraduate curriculum programs). Since mental disorders are increasing in prevalence, for example major depression affects approximately 340 million people worldwide (26), with a prevalence at lifetime of around $20.6 \%(27)$, and up to $33.7 \%$ of people are affected by an anxiety disorder during their lifetime (28), the need training in mental Health for physical therapists is encouraged.

Our finding about the need for more information and/or training on managing physical conditions that affect people with mental disorders, is consistent with previous studies $(15,29)$. Education among physiotherapists should include psychopathology, available treatments of mental disorders in general, and frequent comorbid physical comorbidities (30). In addition, communication techniques should be improved.

In Paraguay, the first initiative carried out jointly between resident physicians of Psychiatry and resident physiotherapists of the National University of Asunción (involving the Department of Psychiatry and the Department of Kinesiology and Physiotherapy of the School of Medical Sciences of the National University of Asunción), led to training opportunities. As a result, a first Paraguayan book has been published on the topic (3), as well as scientific articles $(13,18,31)$.

In our study, it is noteworthy that a non-negligible number of physical therapists considered that they needed more information about how to interact and communicate with people with mental disorders (21.93\%) and how to assess the behavioral risk and risk of aggressiveness towards health professionals (16.04\%). Some researchers have already reported the existence of such beliefs among health professionals, including physical therapists (32-35).

Stigma may also limit access to health services for people with mental disability (36). Education on Mental Health (and mental disorders) is also essential to reduce prejudices and discrimination (37). Educational processes should include elements on risk assessment, substance abuse and how to manage aggressive patients (38-41).

Importantly, in this study, the majority of people seen by physical therapists were isolated cases and not referred by general practitioners. The lack of medical referral to Physiotherapy has been pointed out by some other authors (4). Musculoskeletal complains among psychiatric patients were mostly managed by the surveyed physiotherapists in this study: this may reflect that Physiotherapists do not generally treat physical symptoms of mental disease and general practitioners are not referring them. Nonetheless, a large majority $(75.94 \%)$ of physical therapists stated that they were aware that Physiotherapy can be used as treatment of some mental disorders, as an adjunct to both pharmacotherapy and psychotherapy. Physiotherapy in Mental Health may improve physical symptoms and well-being by promoting functional movement, awareness of movement, activity and physical exercise (42). Approaches may include: basic body-awareness therapy (43-45), muscle strengthening $(46,47)$, aerobic exercise $(48-51)$, yoga $(52,53)$, progressive muscle relaxation (54-56), manual therapy (57) and therapeutic Pilates (31), among others. In our study, Jacobson's progressive muscle relaxation and aerobic exercise were recognized as the most effective physiotherapeutic interventions for the treatment of some mental disorders $(22.32 \%$ and $21.47 \%$, respectively).

Participants scored that anxiety disorders (23.88\%), major depression and related disorders (21.99\%), and Alzheimer's disease and other dementias (21.48\%) were those mental disorders benefiting from a physiotherapy intervention. This has been confirmed by previous evidences $(3,15,16,58)$. Also, it is important to emphasize that, currently, aerobic exercise can be used even in monotherapy for mild depression (26). Physiotherapy may improve the symptoms of mental disorders through various approaches: a. improving the overall physical health; b. psychophysiological approach enhancing physical competences related to the body; and c. approach related to psychotherapy, using the body as a gateway to improve the affective and social functioning of the individual $(12,59)$.

Limitations of this study may include the type of sampling used, since, being a non-probabilistic type 
sampling, its results cannot be generalized. However, given its internal validity, it can be considered that the results are applicable for the study-sample. Also, it was not possible to establish a certain degree of causality between the variables but rather they were studied cross-sectionally. Finally, a study-design including a qualitative component is needed to further explore physiotherapists' perceptions of this particular area.

We conclude that Physiotherapy has a potential role in managing the physical needs of people with mental disorders, and there may be a need to strengthen the skills and knowledge of physical therapists in order to address some specific needs of people with mental disorders. An adequate training of professional physiotherapists, starting from undergraduate education, is encouraged (60).

\section{ACKNOWLEDGMENTS}

The authors express their gratitude to Professors Eleanor Andrew, Kathy Briffa, Samantha Lee, Robyn Fary (School of Physiotherapy and Exercise Science, Curtin University, Australia) and Flavie Waters (Clinical Research Center, Graylands Campus, North Metropolitan Health Service Mental Health; and School of Psychiatry and Clinical Neurosciences, University of Western Australia, Perth, Australia) for having kindly authorized the adaptation and translation into Spanish of the survey used in this research..

\section{REFERENCES}

1. Whiteford HA, Ferrari AJ, Degenhardt L, Feigin V, Vos T. The Global Burden of Mental, Neurological and Substance Use Disorders: An Analysis from the Global Burden of Disease Study 2010. PLOS ONE. 2015;10(2):e0116820. https://dx.doi.org/10.1371/journal.pone.0116820

2. Liu $Q$, He H, Yang J, Feng $X$, Zhao F, Lyu J. Changes in the global burden of depression from 1990 to 2017: Findings from the Global Burden of Disease study. J Psychiatr Res. 2020;126:134-40. https://dx.doi.org/10.1016/i.jpsychires.2019.08.002

3. Ortiz R, Ibarra V, Almirón M, González I, Gómez N, Torales J. Fisioterapia en Salud Mental: una breve guía introductoria [Physiotherapy in Mental Health: a brief introductory guide]1st ed.Asunción: EFACIM; 2018.

4. Andrew E, Briffa K, Waters F, Lee S, Fary R. Physiotherapists' views about providing physiotherapy services to people with severe and persistent mental illness: a mixed methods study. J Physiother. 2019;65(4):222-9. https://dx.doi.org/10.1016/i.jphys.2019.08.001

5. Hardy S, White J, Deane K, Gray R. Educating healthcare professionals to act on the physical health needs of people with serious mental illness: a systematic search for evidence: Educating staff about physical health in SMI. J Psychiatr Ment Health Nurs. 2011;18(8):721-7. https://dx.doi.org/10.1111/j.1365-2850.2011.01722.x

6. Grubaugh AL, Clapp JD, Frueh BC, Tuerk PW, Knapp RG, Egede LE. Open trial of exposure therapy for PTSD among patients with severe and persistent mental illness. Behav Res Ther. 2016;78:1-12. https://dx.doi.org/10.1016/j.brat.2015.12.006

7. Alexandratos $K$, Barnett $F$, Thomas $Y$. The Impact of Exercise on the Mental Health and Quality of Life of People with Severe Mental Illness: A Critical Review. Br J Occup Ther. 2012;75(2):48-60.

https://dx.doi.org/10.4276/030802212X13286281650956

8. Knapik GP, Graor CH. Engaging Persons with Severe Persistent Mental Illness into Primary Care. J Nurse Pract. 2013;9(5):283-7.

https://dx.doi.org/10.1016/j.nurpra.2013.02.019

9. Robson D, Gray R. Serious mental illness and physical health problems: A discussion paper. Int J Nurs Stud. 2007;44(3):457-66.

https://dx.doi.org/10.1016/j.ijnurstu.2006.07.013

10. Dickerson F, Origoni A, Schroeder J, Schweinfurth LAB, Stallings $C$, Savage CLG, et al. Mortality in schizophrenia and bipolar disorder: Clinical and serological predictors. Schizophr Res. 2016;170(1):177-83. https://dx.doi.org/10.1016/j.schres.2015.11.010

11. Torales J, Arce A. Principios de psicofarmacología: una introducción [Principles of Psychopharmacology: an introduction]. Med Clínica Soc. 2017;1(1):54-99.

12. Vancampfort D, Stubbs B, Ward PB, Teasdale S, Rosenbaum $\mathrm{S}$. Why moving more should be promoted for severe mental illness. Lancet Psychiatry. 2015;2(4):295. https://dx.doi.org/10.1016/S2215-0366(15)00099-1

13. Torales J, Barrios I, Almirón M, De la Cueva R. Physiotherapy in the treatment of anxiety disorders. Int J Cult Ment Health. 2017;10(3):298-9. https://dx.doi.org/10.1080/17542863.2017.1303075

14. Richardson CR, Faulkner G, McDevitt J, Skrinar GS, Hutchinson DS, Piette JD. Integrating Physical Activity Into Mental Health Services for Persons With Serious Mental Illness. Psychiatr Serv. 2005;56(3):324-31. https://dx.doi.org/10.1176/appi.ps.56.3.324

15. Pope C. Recovering mind and body: a framework for the role of physiotherapy in mental health and well-being. J Public Ment Health. 2009;8(2):36-9. https://dx.doi.org/10.1108/17465729200900012

16. Probst M. Physiotherapy and Mental Health. In: Suzuki T, editor. Clin. Phys. Ther. 1st ed., London: InTech; 2017, p. 179-204.

17. Guszkowska M. [Effects of exercise on anxiety, depression and mood]. Psychiatr Pol. 2004;38(4):611-20.

18. Torales J, Almirón M, González I, Gómez N, Ortiz R, Ibarra V. Ejercicio físico como tratamiento adyuvante de los trastornos mentales. Una revisión narrativa. An Fac Cienc Méd (Asunción). 2018;51(3):27-32. https://dx.doi.org/10.18004/anales/2018.051(03)27-032

19. Morgan VA, Waterreus A, Jablensky A, Mackinnon A, McGrath JJ, Carr V, et al. People living with psychotic illness in 2010: The second Australian national survey of psychosis. Aust N Z J Psychiatry. 2012;46(8):735-52. https://dx.doi.org/10.1177/0004867412449877

20. Lee S, Waters F, Briffa K, Fary RE. Limited interface between physiotherapy primary care and people with severe mental illness: a qualitative study. J Physiother. 2017;63(3):168-74.

https://dx.doi.org/10.1016/i.jphys.2017.05.014

21. Vancampfort D, Knapen J, Probst M, Scheewe T, Remans S, De Hert M. A systematic review of correlates of physical activity in patients with schizophrenia: Physical activity correlates in schizophrenia. Acta Psychiatr Scand. 2012;125(5):352-62. https://dx.doi.org/10.1111/i.16000447.2011.01814.x

22. Stubbs B, Soundy A, Probst M, De Hert M, De Herdt A, 
Vancampfort D. Understanding the role of physiotherapists in schizophrenia: an international perspective from members of the International Organisation of Physical Therapists in Mental Health (IOPTMH). J Ment Health. 2014;23(3):125-9.

https://dx.doi.org/10.3109/09638237.2013.869574

23. Stubbs B, Soundy A, Probst M, Parker A, Skjaerven LH, Lundvik Gyllensten $A$, et al. Addressing the disparity in physical health provision for people with schizophrenia: an important role for physiotherapists. Physiotherapy. 2014;100(3):185-6.

https://dx.doi.org/10.1016/j.physio.2013.11.003

24. Stubbs B, Probst M, Soundy A, Parker A, De Herdt A, De Hert $M$, et al. Physiotherapists can help implement physical activity programmes in clinical practice. $\mathrm{Br} J$ Psychiatry. 2014;204(2):164-164.

https://dx.doi.org/10.1192/bjp.204.2.164

25. Connaughton J, Gibson W. Physiotherapy Students' Attitudes toward Psychiatry and Mental Health: A CrossSectional Study. Physiother Can. 2016;68(2):172-8. https://dx.doi.org/10.3138/ptc.2015-18E

26. Torales J, Arce A, Chávez E, Melgarejo O. Trastornos depresivos: de la etiopatogenia a la terapéutica [Depressive disorders: from etiopathogenesis to therapeutics]1st ed.Asunción: EFACIM; 2018.

27. Hasin DS, Sarvet AL, Meyers JL, Saha TD, Ruan WJ, Stohl $M$, et al. Epidemiology of Adult DSM-5 Major Depressive Disorder and Its Specifiers in the United States. JAMA Psychiatry. 2018;75(4):336. https://dx.doi.org/10.1001/jamapsychiatry.2017.4602

28. Bandelow B, Michaelis S. Epidemiology of anxiety disorders in the 21st century. Dialogues Clin Neurosci. 2015;17(3):327-35.

29. Vancampfort D, Rosenbaum S, Probst M, Connaughton J, du Plessis C, Yamamoto T, et al. Top 10 research questions to promote physical activity in bipolar disorders: A consensus statement from the International Organization of Physical Therapists in Mental Health. J Affect Disord. 2016;195:82-7.

\section{https://dx.doi.org/10.1016/i.jad.2016.01.046}

30. Vancampfort D, De Hert M, Skjerven LH, Gyllensten AL, Parker A, Mulders N, et al. International Organization of Physical Therapy in Mental Health consensus on physical activity within multidisciplinary rehabilitation programmes for minimising cardio-metabolic risk in patients with schizophrenia. Disabil Rehabil. 2012;34(1):1-12. https://dx.doi.org/10.3109/09638288.2011.587090

31. Torales J, Almirón M, González I, Navarro R, O’Higgins M, Castaldelli-Maia J, et al. ¿Mejora el PILATES la salud mental? Mem Inst Investig En Cienc Salud. 2019;17(3):97-102. https://dx.doi.org/10.18004/mem.iics/18129528/2019.017.03.97-102

32. Peer JR, Warnecke AJ, Baum CA, Goreczny AJ. Stigmatization of People with Schizophrenia: Perspectives of Graduate Students in Various Healthcare Fields. Int J Ment Health. 2015;44(3):186-99. https://dx.doi.org/10.1080/00207411.2015.1035065

33. Rao H, Mahadevappa H, Pillay P, Sessay M, Abraham A, Luty J. A study of stigmatized attitudes towards people with mental health problems among health professionals. J Psychiatr Ment Health Nurs. 2009;16(3):279-84. https://dx.doi.org/10.1111/j.1365-2850.2008.01369.x

34. Setchell J. What Has Stigma Got to Do with Physiotherapy? Physiother Can. 2017;69(1):1-3. https://dx.doi.org/10.3138/ptc.69.1.GEE

35. Clement S, Schauman O, Graham T, Maggioni F, Evans-
Lacko S, Bezborodovs N, et al. What is the impact of mental health-related stigma on help-seeking? A systematic review of quantitative and qualitative studies. Psychol Med. 2015;45(1):11-27. https://dx.doi.org/10.1017/S0033291714000129

36. Torales J, Girala N, Garcete M, Forestieri F. Derechos Humanos en Paraguay 2007 [Human Rights in Paraguay 2007]Asunción: AGR Editorial; 2007.

37. Stubbs A. Reducing mental illness stigma in health care students and professionals: a review of the literature. Australas Psychiatry. 2014;22(6):579-84. https://dx.doi.org/10.1177/1039856214556324

38. Fazel S. Schizophrenia, Substance Abuse, and Violent Crime. JAMA. 2009;301(19):2016. https://dx.doi.org/10.1001/iama.2009.675

39. Recalde Berni S, Torales J, Arce A. Esquizofrenia y violencia [Schizophrenia and violence]. Rev Par Psiq. 2015;3(1):57-66.

40. Arce A, Moreno $M$, Torales J, Rodríguez $H$, Bogado A, Medina A. Normas generales para personas usuarias de Salud Mental, sus familias y cuidadores generales [Rules for users of Mental Health services, their families and caregivers]3rd ed.Asunción: EFACIM; 2017.

41. Bernardo M, Córdoba R, Torales J, Barrios I, editors. ¿Qué sabemos de la Esquizofrenia? Guía para pacientes y familiares1st ed.Antigua: Asociación Psiquiátrica de América Latina; 2016.

42. Catalán-Matamoros D. Fisioterapia en Salud Mental. Efectividad de una intervención fisioterapéutica en trastornos alimentarios [Physiotherapy in Mental Health effectiveness of a physiotherapeutic intervention in eating disorders]. Universidad de Málaga, 2007.

43. Sobel D, Ornstein R. Manual de la Salud del Cuerpo y la Mente [Mind and Body Health Manual]1st ed.Barcelona: Kairós; 2000.

44. Catalan-Matamoros D, Helvik-Skjaerven L, LabajosManzanares MT, Martínez-de-Salazar-Arboleas A, SánchezGuerrero E. A pilot study on the effect of Basic Body Awareness Therapy in patients with eating disorders: a randomized controlled trial. Clin Rehabil. 2011;25(7):61726. https://dx.doi.org/10.1177/0269215510394223

45. Danielsson L, Rosberg S. Opening toward life: Experiences of basic body awareness therapy in persons with major depression. Int J Qual Stud Health Well-Being. 2015;10(1):27069.

https://dx.doi.org/10.3402/qhw.v10.27069

46. Fernandez-del-Valle $M$, Larumbe-Zabala E, VillaseñorMontarroso A, Cardona Gonzalez C, Diez-Vega I, Lopez Mojares LM, et al. Resistance training enhances muscular performance in patients with anorexia nervosa: A randomized controlled trial: Resistance Training in Anorexia Nervosa. Int J Eat Disord. 2014;47(6):601-9. https://dx.doi.org/10.1002/eat.22251

47. Scheewe TW, Backx FJG, Takken T, Jörg F, van Strater ACP, Kroes $A G$, et al. Exercise therapy improves mental and physical health in schizophrenia: a randomised controlled trial. Acta Psychiatr Scand. 2013;127(6):464-73. https://dx.doi.org/10.1111/acps.12029

48. Scheewe TW, van Haren NEM, Sarkisyan G, Schnack HG, Brouwer RM, de Glint $M$, et al. Exercise therapy, cardiorespiratory fitness and their effect on brain volumes: A randomised controlled trial in patients with schizophrenia and healthy controls. Eur Neuropsychopharmacol. 2013;23(7):675-85.

https://dx.doi.org/10.1016/j.euroneuro.2012.08.008

49. Lowery D, Cerga-Pashoja A, Iliffe S, Thuné-Boyle I, Griffin 
$M$, Lee J, et al. The effect of exercise on behavioural and psychological symptoms of dementia: the EVIDEM-E randomised controlled clinical trial: Exercise for behavioural symptoms of dementia. Int J Geriatr Psychiatry. 2014;29(8):819-27. https://dx.doi.org/10.1002/gps.4062

50. Krogh J, Rostrup E, Thomsen C, Elfving B, Videbech $P$, Nordentoft $M$. The effect of exercise on hippocampal volume and neurotrophines in patients with major depression-A randomized clinical trial. J Affect Disord. 2014;165:24-30.

https://dx.doi.org/10.1016/j.jad.2014.04.041

51. Yoon JE, Lee SM, Lim HS, Kim TH, Jeon JK, Mun MH. The Effects of Cognitive Activity Combined with Active Extremity Exercise on Balance, Walking Activity, Memory Level and Quality of Life of an Older Adult Sample with Dementia. J Phys Ther Sci. 2013;25(12):1601-4. https://dx.doi.org/10.1589/ipts.25.1601

52. Vancampfort $D$, Vansteelandt $K$, Scheewe T, Probst $M$, Knapen J, De Herdt A, et al. Yoga in schizophrenia: a systematic review of randomised controlled trials: Yoga in schizophrenia. Acta Psychiatr Scand. 2012;126(1):12-20. https://dx.doi.org/10.1111/j.1600-0447.2012.01865.x

53. Mitchell KS, Dick AM, DiMartino DM, Smith BN, Niles B, Koenen KC, et al. A Pilot Study of a Randomized Controlled Trial of Yoga as an Intervention for PTSD Symptoms in Women: Yoga for PTSD in Women. J Trauma Stress. 2014;27(2):121-8. https://dx.doi.org/10.1002/jts.21903

54. Vancampfort D, De Hert M, Knapen J, Maurissen K, Raepsaet J, Deckx S, et al. Effects of progressive muscle relaxation on state anxiety and subjective well-being in people with schizophrenia: a randomized controlled trial. Clin Rehabil. 2011;25(6):567-75. https://dx.doi.org/10.1177/0269215510395633

55. Conrad A, Roth WT. Muscle relaxation therapy for anxiety disorders: It works but how? J Anxiety Disord. 2007;21(3):243-64.

https://dx.doi.org/10.1016/j.janxdis.2006.08.001

56. Pifarré $P$, Simó $M$, Gispert J-D, Plaza P, Fernández A, Pujol J. Diazepam and Jacobson's Progressive Relaxation Show Similar Attenuating Short-Term Effects on Stress-Related Brain Glucose Consumption. Eur Psychiatry. 2015;30(2):187-92.

https://dx.doi.org/10.1016/j.eurpsy.2014.03.002

57. Moyle W, Cooke ML, Beattie E, Shum DHK, O'Dwyer ST, Barrett $S$, et al. Foot Massage and Physiological Stress in People with Dementia: A Randomized Controlled Trial. J Altern Complement Med. 2014;20(4):305-11. https://dx.doi.org/10.1089/acm.2013.0177

58. Kaur J, Garnawat D. The mental health benefits of physiotherapy. Fysioterapeuten. 2016;7:33-6.

59. Probst M, Knapen J, Poot G, Vancampfort D. Psychomotor Therapy and Psychiatry: What's in a Name? Open Complement Med J. 2010;2(1):105-13.

60. Catalán Matamoros D. La Fisioterapia en Salud Mental: su efectividad y situación actual [Physiotherapy in Mental Health: its effectiveness and current status]. Fisioterapia. 2009;31(5):175-6.

https://dx.doi.org/10.1016/j.ft.2009.09.001 